\title{
Porewater drainage and dissolved organic carbon and nutrient losses through the intertidal creekbanks of a New England salt marsh
}

\author{
Brian L. Howes, Dale D. Goehringer \\ Biology Department, Woods Hole Oceanographic Institution, Woods Hole, Massachusetts 02543, USA
}

\begin{abstract}
D Drainage of interstitial water from creekbanks vegetated by tall Spartina alterniflora was directly measured using an in situ chamber technique over complete tidal cycles throughout the year in the Great Sippewissett Salt Marsh, Massachusetts, USA. Estimates of porewater seepage into chambers compared favorably with water exchange calculated from parallel measurements of water table excursion and sediment-specific yield when plants were inactive. Upon low tide exposure of the marsh surface, there was an initial large loss of porewater, then a continuously declining discharge which paralleled the pattern of water table drop in the adjacent creekbank sediments. Seepage losses were related to the vertical height of the creekbank with banks ranging from 0.5 to $1.0 \mathrm{~m}$ showing more than a 3-fold greater discharge than those only 0.25 to $0.5 \mathrm{~m}$ high on a linear basis and nearly 2 -fold greater on an areal basis. Strong seasonal variations in seepage volume and extent of low tide water table excursion occurred in the tall S. alterniflora zone. In summer when water removal was through both drainage and evapotranspiration, the water table fell at almost twice the rate as in winter when drainage predominated. The annually averaged volume of creekbank seepage was $15.2 \mathrm{l} \mathrm{m}^{-2}$ or $8.9 \mathrm{l}$ $\mathrm{m}^{-1}$ per tide. The magnitude of the seepage pathway for organic matter and nutrient export from marsh sediments was assessed from simultaneous measurements of seepage volume and concentrations of DOC, $\mathrm{NH}_{4}{ }^{+}, \mathrm{NO}_{3}{ }^{-}+\mathrm{NO}_{2}{ }^{-}$, and $\mathrm{PO}_{4}{ }^{3-}$ in both seepage and tidal waters. Sediments underlying tall $S$. alterniflora showed a net export of DOC of $1080 \mathrm{mmol} \mathrm{C} \mathrm{m}{ }^{-2} \mathrm{yI}^{-1}\left(544 \mathrm{mmol} \mathrm{m}{ }^{-1} \mathrm{yr}^{-1}\right), \mathrm{NH}_{4}{ }^{*} 115 \mathrm{mmol}$ $\mathrm{m}^{-2} \mathrm{yr}^{-1}\left(57 \mathrm{mmol} \mathrm{m}{ }^{-1} \mathrm{yr}^{-1}\right)$, and $\mathrm{NO}_{3}{ }^{-}+\mathrm{NO}_{2}-6.5 \mathrm{mmol} \mathrm{m}{ }^{-2} \mathrm{yr}^{-1}\left(4.7 \mathrm{mmol} \mathrm{m}{ }^{-1} \mathrm{yr}^{-1}\right)$, while $\mathrm{PO}_{4}{ }^{3-}$ was imported from tidal waters. Measured dissolved inorganic nitrogen losses in drainage waters represent only about $3 \%$ of the inorganic nitrogen export from this marsh. While porewater drainage was a major factor in the water budget of creekbank areas and represents a potential aeration subsidy to sediment oxidation, it was not found to be a significant pathway for the transter of organic carbon or inorganic nutrients from the Spartina root zone to tidal waters.
\end{abstract}

KEY WORDS: Salt marsh $\cdot$ Spartina $\cdot$ Hydrology $\cdot$ DOC $\cdot$ Nitrogen

\section{INTRODUCTION}

Salt marshes have long been considered to be sources of organic matter to adjacent coastal waters (Teal 1962, Odum \& de la Cruz 1967) and foci of nutrient cycling in estuaries (cf. Nixon 1980). Direct measurement of carbon and nitrogen fluxes in tidal exchange in both whole system (cf. Valiela 1983) and sub-marsh studies (Whiting et al. 1989, Jordan \& Correll 1991) support the general conclusion of organic matter export, uptake of nitrate and loss of ammonium from marshes to tidal waters.
The initial hypothesis suggesting that outwelling from salt water wetlands may occur (Odum 1980) was put forward based on the measured high aboveground production of the grasses (notably Spartina alterniflora, the dominant macrophyte in Atlantic coastal marshes; cf. Turner 1976), and the relatively small amount of grazing on live plants (Teal 1962, Vince et al. 1981). The bulk of the above-ground production is therefore available to support detrital food chains, providing a mechanism for the subsidy of estuarine secondary production. Similar to initial arguments based upon the aerial portions of the plants, 
the finding that most of the annual production of Spartina spp. is in roots and rhizomes (cf. Good et al. 1982) led to investigations of potential pathways for the large below-ground carbon and nitrogen pools to contribute to wetland export. Mechanisms for belowground to tidal water transfers have necessarily focused on dissolved export through the marsh surface (Gardner 1975, Hemond et al. 1984) or via drainage of porewater through creekbanks (Agosta 1985, Jordan \& Correll 1985, Yelverton \& Hackney 1986), although loss of particulate and dissolved material generated below-ground has been found to be facilitated by bioturbation, particularly by fiddler crabs (Katz 1980, Montague 1982).

Indications that Spartina productivity may be related to the rate of porewater turnover within the rooting zone has stimulated interest in the subsurface hydrology of vegetated areas of intertidal marshes (Wiegert et al. 1983, Howes et al. 1986). Typically, along the banks of tidal creeks where plant productivity is highest, low tide water tables are deeper than in less productive areas a few meters inland. The lower creekbank water table results from the addition of porewater drainage to the water removal by evapotranspiration which occurs throughout the vegetated marsh (Howes et al. 1981, Hemond \& Fifield 1982). The processes underlying the association of increased plant productivity with increased water table excursion appears to operate both directly through advective removal of dissolved species, primarily dissolved sulfide (King et al. 1982, Mendelssohn \& McKee 1988), or elevated salinity (Nestler 1977a), and indirectly through increased sediment oxidation due to increased air entry (Howes et al. 1986). In addition, inter-marsh comparisons of plant productivity suggest a positive relationship with tide range (Steever et al. 1976) which may be related to subsurface water movement (Harvey et al. 1987, Nuttle 1988). Clearly an understanding of subsurface hydrology is important to both evaluating material exchanges through tidal water as well as determining the factors controlling the rates of primary production in intertidal wetlands

A wide variety of methods have been used in attempts to quantify both the rates and pathways of porewater loss from salt marsh sediments. Methods include geochemical budgets (Howarth \& Teal 1979), physical budgets (e.g heat; Redfield 1965) and hydrologic models generally based upon Darcy's law (Jordan \& Correll 1985, Yelverton \& Hackney 1986. Harvey et al. 1987, Nuttle 1988) and measures with dyes (Nestler 1977b, Jordan \& Correll 1985), surface chambers (Hemond et al. 1984, Yelverton \& Hackney 1986), and changes in wet weight of sediment (Valiela et al. 1978, Howarth et al. 1983, Agosta 1985). Although some of the methods appear to be insensitive or prone to artifact (e.g. geochemical budgets or weight changes in short Spartina marsh), in general most suggest that porewater loss through creekbanks is restricted to the several meters directly adjacent to the creeks. Direct measurements of subsurface water exchange in short Spartina marsh are consistent with reports of negligible drainage of porewater in these areas, water loss being dominated by evapotranspiration (Hemond \& Fifield 1982, Dacey \& Howes 1984, Howes et al. 1986). There have been few studies, how ever, which have attempted to measure porewater drainage through creekbanks by directly measuring the volumetric flux of the water (Jordan \& Correll 1985), even though collection of seepage water has been used in other geochemical studies (Chambers \& Odum 1990).

In the present study, we made direct measurements of seepage using vertically oriented creekbank seepage chambers which allowed the determination of both volume of porewater discharge and mass flux of dissolved organic carbon (DOC) and dissolved inorganic nutrients (nitrate, ammonium and ortho-phosphate). Water loss to chambers was verified using a sediment water balance determined from measured specific yield and changes in hydraulic head. Seepage was estimated for creekbanks with a range of elevations and throughout the year to assess potential influences of hydraulic gradient and seasonal evapotranspiration on porewater drainage and dissolved export. Measurements were made in Great Sippewissett Marsh, Massachusetts, USA, where whole system tidal exchanges of nitrogen have been quantified (Valiela \& Teal 1979) to assess the potential role of porewater drainage in salt marsh export.

\section{MATERIALS AND METHODS}

Study sites. Seepage from the near-vertical face of creekbanks was investigated at 3 sites with highly organic sediments ( 15 to $25 \%$ carbon) typical of New England pocket marshes. Only creekbanks extending 25 to $100 \mathrm{~cm}$ above the creek bottom and vegetated by Spartina alterniflora, representing $95 \%$ of the tidal creek bank in Great Sippewissett Marsh, were assayed.

Seepage measurements. Seepage chambers $(28.9 \mathrm{~cm}$ i.d., $12 \mathrm{~cm}$ long) were thin walled (1 $\mathrm{mm}$ ) with an open and a sealed (flat) end. Chambers were inserted 7 to $9 \mathrm{~cm}$ into the creekbank with the closed end nearly vertical so that water within the chamber would flow to a port at the lowest point of the exposed portion of the chamber. A second port situated at the highest point in the chamber allowed air to enter or leave to equilibrate the pressure as water entered or exited. The effect was 
that the sediment surface within the chamber had the same inundation and exposure time as the adjacent creekbank. Water draining through the bottom port was collected in sealed heavyweight polyethylene bags (12 l capacity, $38 \times 62 \mathrm{~cm}$ ) attached via $15 \mathrm{~cm}$ of Tygon tubing. Because sampling was initiated at high tide when the chamber headspace was filled with water, all water volumes were corrected for the headspace volume (ca 2.5 l). This volume was determined by rapidly filling and draining the headspace several times in succession until a constant volume was determined; these results agreed with values calculated from the measured dimensions of each headspace. The chambers were painted white to prevent photosynthesis by surface algae or diatoms and to minimize increases in sediment temperature. No significant difference was found in seepage rates 2 and $10 \mathrm{~d}$ after insertion.

Seepage measurements began when the falling tide was level with the top port of each chamber, and measurements continued until the following flood tide reached the bottom of the chamber. The initial sample was collected when the water level reached the bottom of each chamber and included water from the headspace plus any seepage during this interval, usually about $1.5 \mathrm{~h}$. After the initial sample, collection contained only seepage water with measurements at 1 to $1.5 \mathrm{~h}$ intervals. At each sampling, the volume of water was measured, and subsamples for nutrient analysis filtered (0.22 $\mu \mathrm{m}$, Millipore) into $\mathrm{HCl}$-leached Nalgene bottles $(125 \mathrm{ml})$ and transported on ice to the laboratory. Additional samples of the tidal water flooding over the creekbank and 4 to 6 samples of creek water were collected throughout each run. Seepage and creek waters were analyzed for $\mathrm{DOC}, \mathrm{NH}_{4}{ }^{+}$, and salinity on all samples and for $\mathrm{NO}_{3}{ }^{-}, \mathrm{NO}_{2}{ }^{-}$, and $\mathrm{PO}_{4}{ }^{3-}$ on selected samples. Except for some of the $\mathrm{NO}_{3}{ }^{-}$and $\mathrm{NO}_{2}{ }^{-}$samples which were frozen $\left(-15^{\circ} \mathrm{C}\right)$ for later analysis, all assays were performed within $24 \mathrm{~h}$ of sample collection.

We were concerned about potential artifacts caused by the method of seepage water collection, particularly the effects of cutting of root and rhizome material during insertion and the shading of the sediment surface within the chambers. As the chamber was of large diameter $(28.5 \mathrm{~cm})$ and was inserted $<10 \mathrm{~cm}$ into the vertical face of the creekbank where there are no plant shoots, the input of DOC, etc. leaching from cut roots and rhizomes (Howes et al. 1985b) should have been small. The potential for creating artificially high DOC concentrations was further reduced by allowing several days to elapse between chamber placement and sampling, during which seepage through these surficial sediments continued. There was no visible change in the appearance of the sediment surface (e.g. color, texture, formation of precipitates) when the chambers were removed after sampling. The shallow insertion of the chamber relative to the distances traveled by seepage water per tide further reduced the likelihood of chamber effects. The impact on the volume of seepage measured should also be minor since the depth of penetration was $<10 \mathrm{~cm}$, rates showed no consistent bias through several weeks following insertion, and hydraulic gradients suggest flow nearly directly along the long axis of the chambers as placed.

To further confirm the validity of the chamber measurements, we determined total water and solute loss at one of the chamber sites from a water budget and porewater sampling. In the budget, water loss was estimated from measured water table drop and specific yield of the sediments. The loss of water was calculated at the $1 \mathrm{~h}$ intervals of well monitoring with parallel measurements of seepage from 4 chambers positioned in the adjacent creekbank. During these parallel studies, porewater was collected using sippers (Howes et al. $1985 \mathrm{~b}$ ) at $5,10,20,30,40,50 \mathrm{~cm}$ depths, 0.5 and $1.0 \mathrm{~m}$ inland from the creek. DOC and ammonium concentrations were assayed in order to calculate loss in draining porewater for comparison to directly measured flux to creekbank chambers. In order to minimize water losses to evapotranspiration, comparisons were made in the late fall when the plants were not active and under conditions of low evaporative potential (overcast, cool, ca 50\% humidity).

Water table measurements. Water table depth was monitored in concert with each seepage determination. Wells (PVC, $0.95 \mathrm{~cm}$ i.d., screened through the water table) were placed adjacent to boardwalks in 2 transects perpendicular to the creekbank where each set of chambers were positioned. Deep wells $(40 \mathrm{~cm})$ were placed at $0.3,0.5,0.75$ and $1.0 \mathrm{~m}$, with $30 \mathrm{~cm}$ wells at $1.25,1.5$ and $2.0 \mathrm{~m}$ from the creek edge. Water levels were measured at hourly intervals throughout low tide using a graduated resistance probe, with an accuracy of $1 \mathrm{~mm}$ (Dacey \& Howes 1984).

The role of evapotranspiration in observed water table excursions was determined using lysimeters (25.6 cm i.d., $40 \mathrm{~cm}$ deep) placed in the creekbank tall grass zone $(\mathrm{n}=4)$ and in the adjacent short Spartina directly inland ( 3 to $5 \mathrm{~m}$ from creek, $\mathrm{n}=4$ ). The lysimeters isolate a portion of the plant-sediment system from the surrounding marsh so that water and solute losses can only be across the marsh surface, as lateral and downward porewater flows are prevented. Lysimeters are placed so that there is no impact on surface waterflows and such that there are no detectable alterations to plant canopy of the lysimeter and the surrounding grass stand. Water levels within the lysimeters and $1 \mathrm{~m}$ to either side were monitored with wells (for a detailed description see Dacey \& Howes 1984). 
Specific yield. Five cores $(21 \mathrm{~cm} \mathrm{i.d.} \times 40 \mathrm{~cm}$ long) were collected within the area of maximum water table excursion, 0 to $1 \mathrm{~m}$ from the creek edge, for determination of specific yield for the water budget (see above). Specific yield was determined as in Dacey \& Howes (1984) and Howes et al. (1986). Cores were sealed at the bottom with the exception of a 3-way valved drainage port. Depth of water table was determined by means of a glass tube running from the valve vertically up the side of the core tube. Periodic removal of known quantities of water from the core sequentially lowered the water table, generally in 1 to $3 \mathrm{~cm}$ increments. The top of the cores were covered during assay to prevent evaporation and water levels were allowed to equilibrate between water removals. A total of 3 or 4 determinations were performed upon each core; differences between replicates were small $(<5 \%)$. By measuring the volume required to lower the water table through the excursion observed in the field, we were able to determine the volume of water lost for comparison to seepage measurements.

Profiles of marsh surface elevation. Surface elevations and plant height were determined along each well transect at $25 \mathrm{~cm}$ intervals from the creekbottom into the inland short Spartina alterniflora zone. Creekbank height and chamber and well placement were also surveyed to compare the location of the seepage chambers to the water table excursion and surface elevation of the adjacent marsh.

Chemical analyses. Ammonium was measured on duplicate $5 \mathrm{ml}$ subsamples (0.22 $\mu \mathrm{m}$ Millipore filtered) using an indophenol method (Scheiner 1976) after sparging with $\mathrm{O}_{2}$ to remove dissolved sulfide. $\mathrm{NO}_{3}{ }^{-}$, $\mathrm{NO}_{2}{ }^{-}$, and $\mathrm{PO}_{4}{ }^{3-}$ were also assayed by colorimetric techniques (Wood et al. 1967, Bendschneider \& Robinson 1952, Murphy \& Riley 1962, respectively) on about half the total samples. Salinity was measured using a temperature-compensated American Optical refractometer.

DOC was determined on triplicate $5 \mathrm{ml}$ subsamples in sealed ampules using the persulfate oxidation method of Menzel \& Vaccaro (1964). Immediately upon return to the laboratory, $20 \mathrm{ml}$ of $0.22 \mu \mathrm{m}$ (Millipore) filtered sample were pipetted into pre-combusted screw cap test tubes with teflon cap liners and mixed with $1 \mathrm{ml}$ of $3 \% \mathrm{H}_{3} \mathrm{PO}_{4}{ }^{3-}$ DOC was measured as $\mathrm{CO}_{2}$ after oxidation using a Beckman IR15 infra-red analyzer calibrated with both gaseous $\mathrm{CO}_{2}$ and ampulated glucose standards. Potential DOC contamination from filters was checked by digesting both filtered and unfiltered distilled de-ionized water

Above-ground Spartina biomass. Standing live above-ground biomass of Spartina alterniflora was estimated through the growing season using a heightweight regression (Howes et al. 1986). Biomass was also harvested at the end of the growing season in replicate quadrates $(25 \mathrm{~cm} \times 25 \mathrm{~cm})$ in the tall grass zone adjacent each chamber site. Harvested biomass was sorted into live and dead, and oven dried to constant weight at $60^{\circ} \mathrm{C}$

Creekbank survey of Great Sippewissett Marsh. The surface area of creekbank available for drainage throughout Great Sippewissett Marsh was measured to allow calculations of the contribution of DOC and DIN from creekbank seepage relative to overall marsh export. Total linear creekbank was measured using a planimeter and aerial photographs coupled with direct field measurements. Creekbank vertical seepage area was calculated from the linear estimates and measurements of creekbank height at ca $5 \mathrm{~m}$ intervals over the entire marsh.

\section{RESULTS}

\section{Seepage volume}

The water table tended to follow the surface contour of the sediments. The maximum excursion of the water table within the marsh sediments was greatest nearest the creek with smaller changes inland. The rate of fall of the water table was most rapid in the $1 \mathrm{~m}$ zone nearest the creek and exhibited a continually declining rate of change throughout low tide. In addition to the smaller excursion in the 1 to $3 \mathrm{~m}$ zone, the rate of water table fall did not appear to vary through time (Fig. 1A). Water was replenished by the flooding tide primarily through the horizontal surface of the marsh except in the 0 to $1 \mathrm{~m}$ zone adjacent the creek where water entered laterally as the tide rose (Fig 1A). Although the absolute amount and rate of water table excursion vary, these patterns agree well with measurements from salt marshes with differing sediment types (Agosta 1985, Jordan \& Correll 1985, Yelverton \& Hackney 1986, Nuttle 1988).

The declining rate of water table drop in the creek edge sediments, which contribute the largest amount to discharge, was consistent with the time course of seepage into the chambers. Generally, about $75 \%$ of the flow into the chambers was found in the first half of the low tide interval (Fig. 1B), although seepage continued until flooding by tidal waters with the next tide. No significant differences (paired t-test, $\mathrm{p}<0.05$ ) were observed in the total volume of drainage during spring versus neap tides (Nuttle 1988), probably due to the daily flooding of these sites and the small volume of seepage which occurs with each additional hour of exposure (after $5 \mathrm{~h}$ ). The salinity of seepage waters indicated that discharge was of porewater, not fresh groundwater which occurs at the periphery of this marsh (Valiela \& Teal 1979) 

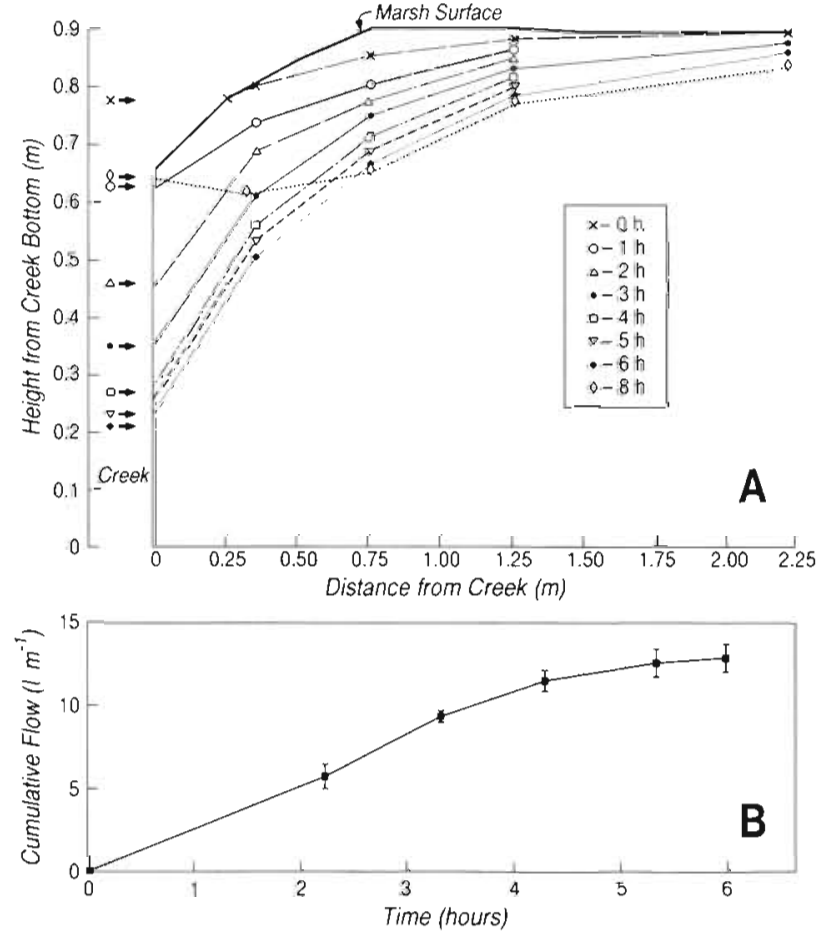

Fig. 1. (A). Cross-section through the creekbank of a Spartina marsh showing the time course of water table drop throughout the low tide period and changes with the rising tide $(8 \mathrm{~h})$ Values are means of duplicate wells, arrows represent creek water level. (B). Time course of water volume draining though the vertical face of the same creekbank at the same time as the water table measures in (A). Seepage volume is relative to a $1 \mathrm{~m}$ width of creekbank. Sampling was in late fall, values are means $\pm \mathrm{SE}$ of 4 replicate seepage chambers

The relative importance of lateral drainage of porewater versus loss to the atmosphere via evapotranspiration varied significantly from the tall creekbank $(0$ to $1 \mathrm{~m}$ ) to the adjacent (>3 to $4 \mathrm{~m}$ ) inland short Spartina areas. Lysimeter measurements during peak above-ground biomass (July-August) indicated that while all of the water table movement in the short zone could be explained by evapotranspiration, drainage played a major role in the water table excursion within creekbanks (Fig. 2). Plant water uptake appeared to continue both day and night in both grass areas as previously observed in control (Dacey \& Howes 1984) and fertilized (Howes et al. 1986) short Spartina marsh. The pattern of plant water uptake explains reports of similar day to night water table drops found in other marshes (Jordan \& Correll 1985, Yelverton \& Hackney $1986)$ but does not indicate that all water loss is through drainage (Howarth et al. 1983).

Water losses from creekbanks from the water budget based upon measured water table excursions and specific yield indicated similar rates to seepage chambers

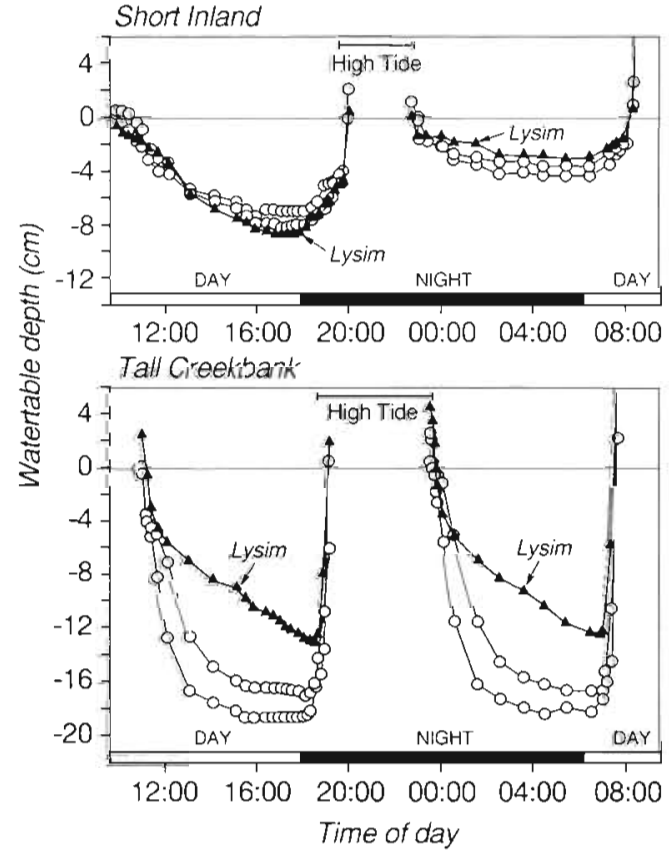

Fig. 2. Time course of water table excursion within a lysimeter and 2 adjacent wells in both a short (upper panel) and tall (lower panel) Spartina alterniflora grass stand. Greater water table drops outside versus inside lysimeters are due to drainage. Plant water uptake occurs both day and night

positioned in the adjacent creekbank. The inland extension of the zone (ca 1.75 to $2.0 \mathrm{~m}$ ) contributing to drainage used in the water budget was based upon the lysimeter data (Fig. 2) and the temporal pattern and rate of water table drop (Fig. 1A). Errors in calculated discharge due to uncertainties of the placement of the inland boundary should be small due to the diminishing contribution to drainage of sediments at increasing distances from the creek. A total of 8 field comparisons were conducted during periods of limited water loss through evapotranspiration. Cores collected within the creekbank area contributing to drainage had a specific yield of 0.036 ( $\mathrm{SE}=0.063, \mathrm{n}=5$ ), slightly higher than the 0.02 to 0.03 reported for short grass areas in this marsh (Dacey \& Howes 1984), probably due to the presence of Uca pugnax burrows, and was the same as for a Virginia, USA, salt marsh 10.032 ; Harvey et al. 1987). The volume of water loss calculated from the budget was consistently slightly higher than measured from the seepage chambers (Table 1 ). The ratio of estimates from chambers versus budgets was 0.91 ( $\mathrm{SE}=$ 0.04). Since some water was lost due to surface evaporation even in fall when these paired measurements were conducted, the higher water 'loss' calculated from the budget might be expected. It appears that the water loss from the creekbanks is not contributing to a potential deeper flow system in this marsh. The good 
Table 1 Comparison of directly measured and calculated porewater drainage through creekbank of Spartina marsh (November). Direct measurements were taken using 4 replicate flux chambers. Water budget was calculated from measured specific yield and maximum water table drop. Values are means (propagated SE)

\begin{tabular}{lccc|}
\hline Method & $\begin{array}{c}\mathrm{H}_{2} \mathrm{O} \text { volume } \\
\left(\mathrm{I} \mathrm{m}^{-1}\right)\end{array}$ & $\begin{array}{c}\mathrm{DOC} \\
\left(\mathrm{mg} \mathrm{C} \mathrm{m}^{-1}\right)\end{array}$ & $\begin{array}{c}\mathrm{NH}_{4}^{+} \\
\left(\mu \mathrm{mol} \mathrm{m}^{-1}\right)\end{array}$ \\
\hline $\begin{array}{lccc}\text { Flux chambers } \\
\text { Water budget }\end{array}$ & $\begin{array}{c}12.6(0.95) \\
\text { Ratio }\end{array}$ & $5.9(1.9)$ & $196(36.6)$ \\
a Concentrations were weighted averages of porewater in \\
zone of water table drop. Loss was corrected for tidal \\
water concentration
\end{tabular}

agreement between these independent techniques suggests that the more easily employed seepage chambers yield an adequate measure of seepage flow through the vertical creekbank surface in this marsh.

The volume of seepage was significantly greater ( $t$-test, $\mathrm{p}<0.05)$ from the higher creekbanks (Fig. 3). The 2- to 3-fold higher drainage from the higher versus lower creekbanks persisted year-round in both linear and areal measures, with annually averaged rates of $13.6(1.6)$ versus $4.2(0.6) \mathrm{l} \mathrm{m}^{-1}$ and 19.3 (2.5) versus $11.1(1.3) \mathrm{lm}^{-2}$, respectively. The difference appears to be positively related to height since when corrected to an area basis the difference in rates persists (Fig. 3).

A seasonal pattern of lower seepage volumes in spring and summer compared to fall and winter was found at both creek heights (Fig. 3). The seasonal pattern suggests that plant water uptake during the growing season effectively 'competes' with drainage in the removal of porewaters most likely by lowering the hydraulic gradient driving seepage. This is consistent with the less pronounced seasonal pattern in the lower creekbanks which had lower peak biomass (600 $\mathrm{g}$ dry wt $\mathrm{m}^{-2}$ ) hence lower leaf area compared to the 0.5 to $1.0 \mathrm{~m}$. high banks (800 to $1500 \mathrm{~g}$ dry wt $\mathrm{m}^{-2}$ ). Comparison of summer versus winter maximum water table excursions also supports the finding of greater seepage in winter due the maintenance of steeper hydraulic gradients when plant water uptake is negligible and loss is primarily by drainage alone (Fig. 4). The role of animal (e.g. Uca pugnax) activity in increasing drainage is unclear, since the highest seepage rates were found during winter when faunal activity is lowest. Seasonal water table measurements also suggest a lower total water loss across the marsh in winter versus summer, of similar magnitude to the summertime evapotranspiration in creekbank versus inland marsh (Fig. 2). These data suggest a seasonal variation in the pathways of water removal with a slight dominance of biological
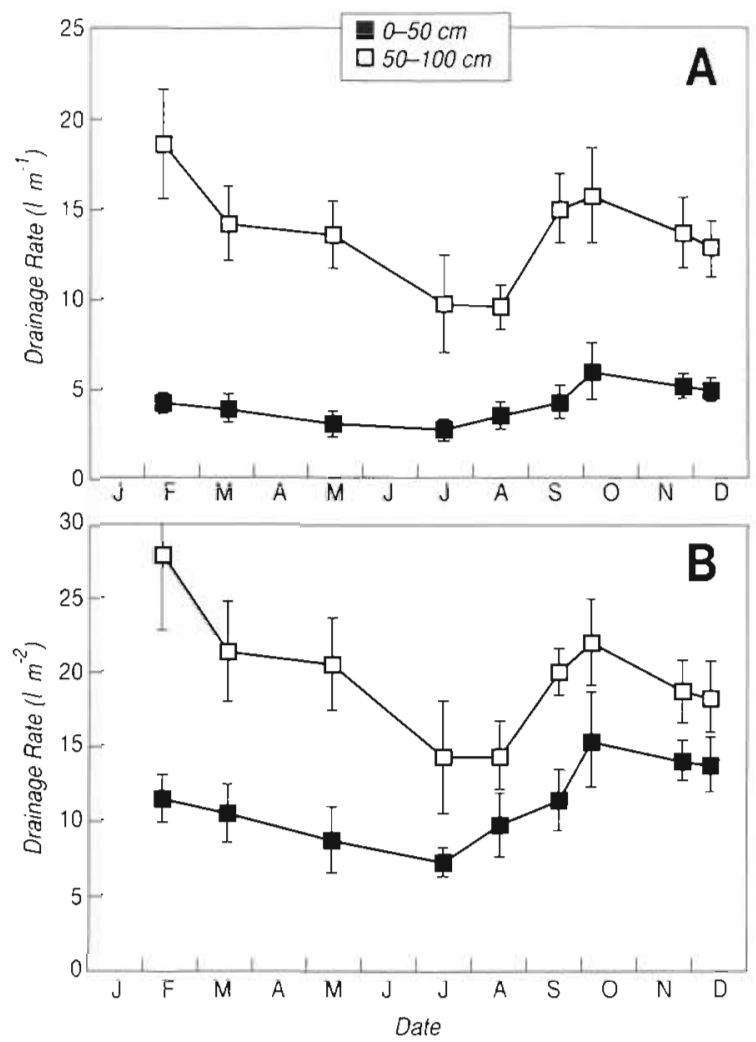

Fig. 3. Mean volume of seepage through creekbanks 0 to $0.5 \mathrm{~m}$ and 0.5 to $1.0 \mathrm{~m}$ in total height above the creek bed. Discharge was determined over complete tidal cycles and is expressed relative to (A) the width of creekbank and (B) to area. Values are means \pm SE $(n=6)$

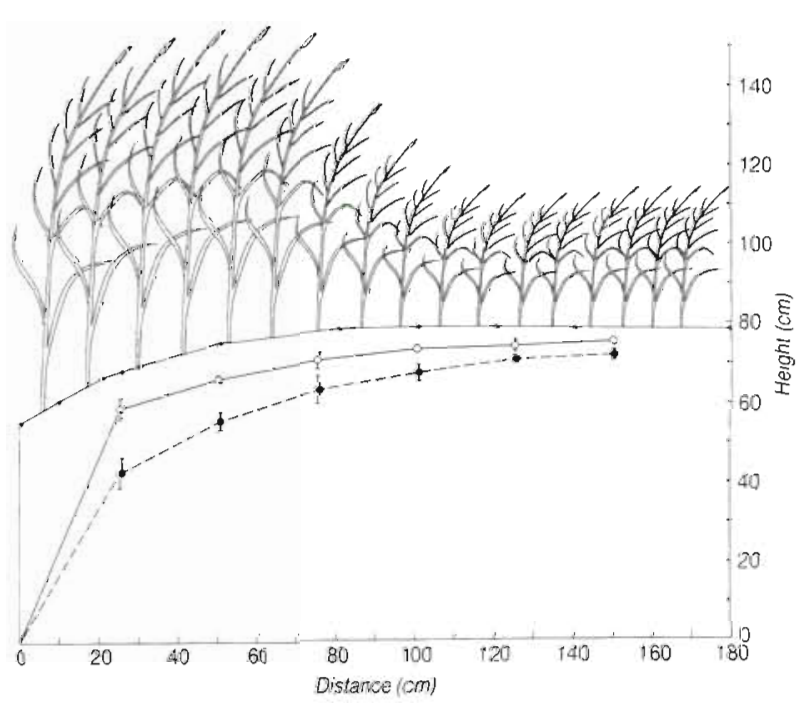

Fig. 4. Comparison of $(0-0)$ winter (December to February) and $(\bullet)$ summer (July to September) maximum water table excursions of 3 marsh cross sections with similar surface elevations. Values are means $\pm \mathrm{SE}(n=9)$. Plant height is the average of the 10 tallest culms measured on each date in summer 
uptake (evapotranspiration) in summer but with the physical processes of drainage (hydraulic head and conductivity) controlling water turnover when the plants are inactive. The mean annual volume of creekbank seepage was $15 \mathrm{l} \mathrm{m}^{-2}$ or $8.91 \mathrm{~lm}^{-1}$ per tide.

\section{Creekbank survey}

The length of creekbank potentially providing seepage to the tidal waters of Great Sippewissett Marsh based on aerial photographs and field survey was $13433 \mathrm{~m}$, with an associated vertical surface area of $6650 \mathrm{~m}^{2}$. These measurements were used to scale the seepage rates (Fig. 3) marsh wide. However, since seepage was not measured from creekbanks smaller than $25 \mathrm{~cm}$ (about $5 \%$ of the total creek length), the rate from the $<0.5 \mathrm{~m}$ banks was applied in the calculations.

\section{Solute fluxes}

Water seeping from the creekbanks carried with it DOC, $\mathrm{NH}_{4}{ }^{+}, \mathrm{NO}_{3}{ }^{-}, \mathrm{NO}_{2}{ }^{-}$, and $\mathrm{PO}_{4}{ }^{3-}$ (data not shown for the last). For the major constituents, DOC and ammonium, the concentration increased significantly through the first few hours and then became relatively constant at the later lower flow rates (Fig. 5). This pattern likely resulted from the greater dilution of the porewater in the initial seepage by the lower concentration creekwater which entered laterally during the previous high tide (cf. Fig. 1), compared to the later seepage water which was from the more interior region of the creekbank and included water which had entered through the horizontal surface of the marsh. Since nitrite levels were always low compared to nitrate they have been combined $\left(\mathrm{NO}_{\mathrm{x}}{ }^{-}\right)$for presentation. In contrast to ammonium, $\mathrm{NO}_{\mathrm{x}}{ }^{-}$ concentrations in seepage were low and varied little through time. These temporal patterns in concentration were seen at all sites throughout the year.

Profiles of DOC and ammonium concentrations in porewater 0.5 and $1.0 \mathrm{~m}$ in from the creek in the tall Spartina zone indicated a fairly uniform distribution of DOC both vertically and horizontally within the marsh. In contrast, ammonium

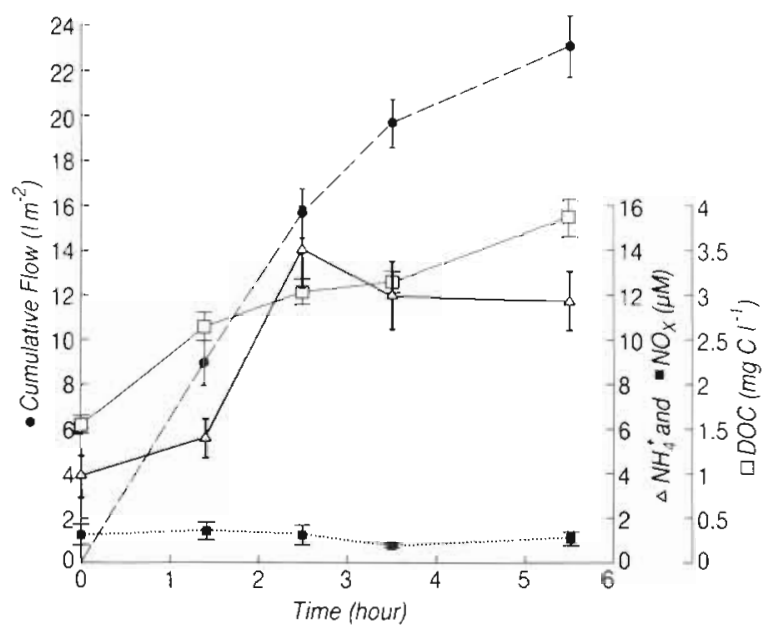

Fig. 5. Time course of seepage volume and associated concentrations of $\mathrm{DOC}, \mathrm{NH}_{4}{ }^{+}$, and $\mathrm{NO}_{x}{ }^{-}$in discharging water. Zero time concentrations are of previous flood tide water. Values are means \pm SE of 3 chambers on each of 3 dates in summer

showed increasing concentrations with depth and significantly higher levels at the $1.0 \mathrm{~m}$ versus the $0.5 \mathrm{~m}$ site (Fig. 6). The greatest rise in ammonium levels was found in the inland profile below $20 \mathrm{~cm}$, the depth range of maximum water table excursion at that location (Fig. 1). For both DOC and ammonium, no significant differences were found between samples collected just after high tide and at the end of low tide $6 \mathrm{~h}$

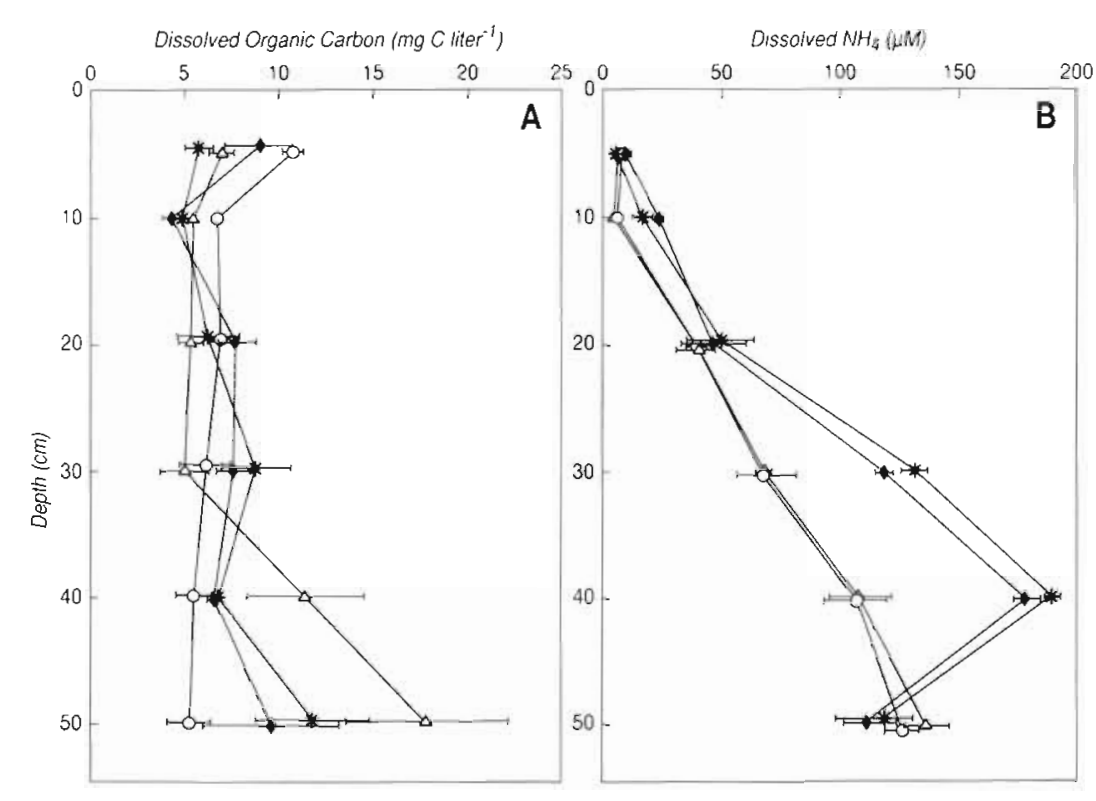

Fig. 6. Profiles of (A) DOC and (B) $\mathrm{NH}_{4}{ }^{+}$concentrations at 2 distances from a creek, just after high tide and at the end of low tide $6 \mathrm{~h}$ later Initial (0:0.5 m; - $1.0 \mathrm{~m})$ and $6 \mathrm{~h}$ samplings $\left(\Delta: 0.5 \mathrm{~m}_{i} *: 1.0 \mathrm{~m}\right)$; means $\pm \mathrm{SE}(\mathrm{n}=2)$ 
later. The temporal stability of the concentrations is likely related to the low specific yield of these sediments which results in only a small loss of water relating to a large water table drop. Since more than $95 \%$ of the water remains in place, dilution with infiltrating water, even though being of much lower concentration, can have only a small effect over a single tide.

Independent estimates of the mass flux of DOC and ammonium in water seeping from the creekbank through complete tidal cycles was determined from the above volumetric flux and concentration data using 2 approaches: (1) a direct estimate from seepage chambers (Fig. 5); and (2) indirectly as calculated from water budget derived seepage volumes and concentrations in the porewater within the adjacent sediments (Fig. 6). Both estimates corrected solute flux for an amount equivalent to the original mass in the infiltrating tidal water. As indicated above, the volume of seepage as determined from these 2 approaches was similar (ratio: 0.87); however, both the DOC and ammonium efflux were significantly smaller when measured with the seepage chambers than when estimated from porewater concentrations (Table 1). The reason is primarily due to the lower concentrations in seepage versus porewater. Biological uptake may be a partial cause, but it is likely that the major effect results from the difficulty in acquiring the necessary spatial resolution in porewater concentrations and in the determination of the relative contribution to total discharge of porewater from different depths. In addition to the effect of lateral inflow in lowering initial concentrations in seepage water (Fig. 5), the focussing of this effect within the 0 to $0.5 \mathrm{~m}$ closest to the creek suggests that porewater concentrations were overestimated by sampling even at the $0.5 \mathrm{~m}$ distance. A similar conclusion was reached when porewater concentrations $2 \mathrm{~m}$ inland from creeks were used to calculate drainage losses in a tidal brackish water marsh (Jordan \& Correll 1985). The difficulties in obtaining adequate spatial porewater concentration measurements may greatly limit the application of this indirect approach to estimating mass losses via seepage.

Comparisons of seasonal mean concentrations of DOC and DIN in flood water versus seepage water suggest that, generally, seepage represents a source of these to tidal water (Fig. 7). In addition, both DOC and ammonium exhibited seasonal trends in seepage concentrations that appear to be related to the growth cycle of Spartina. DOC in seepage water reached maximum levels in spring and summer (Fig, 7 A) coincident with the growth of the plant roots and rhizomes (Valiela et al. 1976) and maximum rates of organic matter decay in this marsh (Howes et al. 1985a). The similarity in DOC levels and seasonal pattern to those of a North Carolina, USA, Spartina
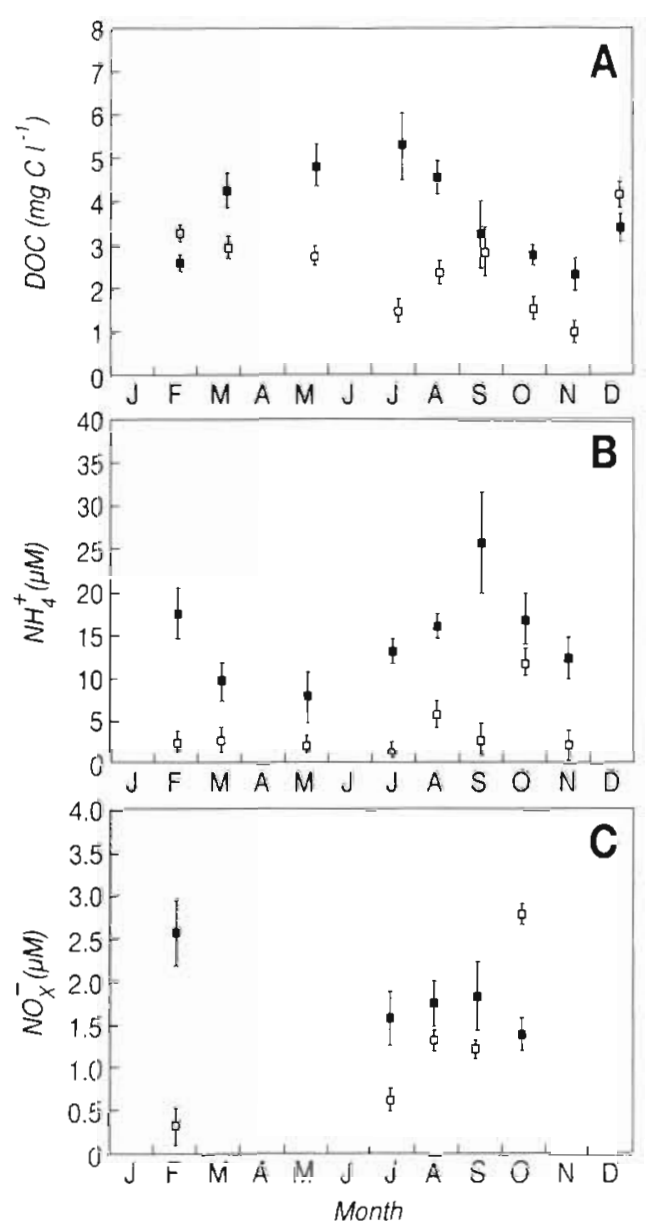

Fig. 7. Seasonal concentrations of (A) DOC, (B) $\mathrm{NH}_{4}{ }^{+}$and (C) $\mathrm{NO}_{x}^{-}$in (G) flood water and ( $\square$ ) seepage waters. Values are means $\pm S E$ of flood water from all locations ( $n=4$ or 5 ) and volume-weighted averages of entire tidal cycles from each chamber $(n=12)$

marsh (Yelverton \& Hackney 1986) further supports a link to the plant cycle when latitudinal and physical differences between the marshes are taken into account. However, these DOC values are more than an order of magnitude lower than earlier DOC concentration estimates for Great Sippewissett Marsh (Howarth \& Hobbie 1982), most likely due to the release of DOC from live plant tissues during sampling (Howes et al. 1985b).

DOC was not lost through seepage throughout the year, as significantly $(p<0.05)$ higher concentrations were found in flooding versus seepage water in midwinter (December to February). The cause for the apparent import of DOC in winter is unclear but may be related to the high DOC concentrations in tidal waters during that period. Ammonium levels in seepage water also appeared to be related to the plant growth and decay cycle with lowest concentrations 
when the plants were growing and taking up nutrients from spring to mid-summer followed by a large increase in fall when the plants senesced (Fig. 7B). Given the partial nitrate data set no seasonal trends can be evaluated, however, similar to ammonium and DOC, seepage waters tended to have higher concentrations than flood water indicative of net loss via seepage. Since nitrate+nitrite levels were low (only about $10 \%$ of dissolved ammonium), ammonium accounted for almost all of the DIN exchanges via the seepage pathway. In contrast to DOC, $\mathrm{NH}_{4}{ }^{+}$, and $\mathrm{NO}_{\mathrm{x}}{ }^{-}$ which showed losses through seepage at least part of the year, $\mathrm{PO}_{4}{ }^{3-}$ levels in seepage were consistently about $30 \%$ that of infiltrating tidal water $(0.19 \pm$ $0.24 \mu \mathrm{M}$ versus $0.64 \pm 0.10 \mu \mathrm{M}, \mathrm{n}=70$ ). Since the results were similar in both summer and winter, creekbank sediments appear to act as a sink for $\mathrm{PO}_{4}{ }^{3-}$ in this marsh. The large drop in $\mathrm{PO}_{4}{ }^{3-}$ concentration probably results from iron-phosphate interactions within the surficial sediments similar to those reported for a tidal freshwater marsh (Chambers \& Odum 1990), but more work is needed to confirm this mechanism

The average 'export' or 'import' of DOC and ammonium through the creekbank seepage pathway was determined as the mean of the individual seepage and concentrations measures ( $n=12$ ) for each seepage chamber on each sampling date. Therefore, seasonal changes in net flux result from seasonal cycles of seepage volume and solute concentration. Since the cycle of seepage volume was out of phase with that of DOC concentration (Figs. $3 \& 7$ ), a relatively constant export of DOC was found throughout most of the year. However, as suggested from the concentration data (Fig. 7A), a net DOC import to the sediments occurred in winter (Fig. 8). In contrast, ammonium inputs and outputs were in balance through the early part of the growing season but exhibited a large release in fall. The seasonal pattern of export of ammonium in seepage is similar to the pattern of the loss from Great

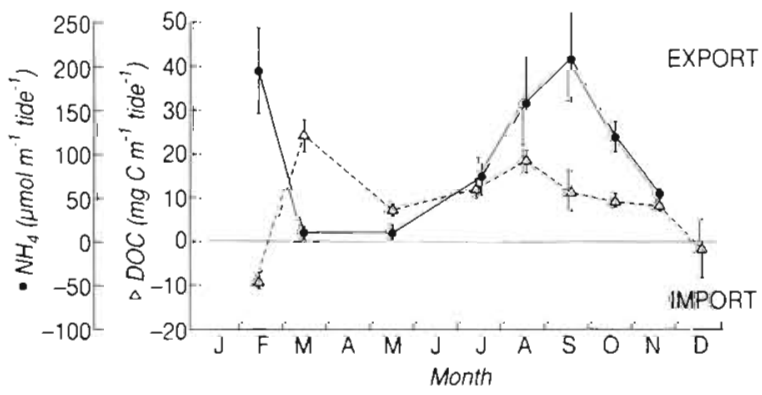

Fig. 8. Seasonal seepages losses of $\mathrm{DOC}$ and $\mathrm{NH}_{4}{ }^{+}$per width of creekbank. Net losses over infiltrating tidal water represent 'export' while net uptake by the vegetated marsh sediments represent 'import'. Values are means $\pm \mathrm{SE}$ of all sites
Sippewissett Marsh found in fall tidal exchanges (Valiela \& Teal 1979)

Integrating the flux data over the year it appears that both DOC and DIN show net annual exports from creekbanks through seepage. Total annual export of DOC to tidal waters was $17.5 \mathrm{mg} \mathrm{C} \mathrm{m}^{-2}$ of creek edge tide ${ }^{-1}$ or $85 \mathrm{~kg} \mathrm{C} \mathrm{yr}^{-1}$ for the entire marsh, while $\mathrm{NH}_{4}^{+}$

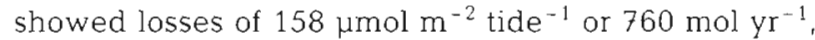
respectively. Using the available data on $\mathrm{NO}_{3}{ }^{-}+\mathrm{NO}_{2}$ we estimate a small annual net loss of $\mathrm{NO}_{x}{ }^{-}$of $13 \mu \mathrm{mol}$ $\mathrm{m}^{-2}$ of creek edge tide ${ }^{-1}$ or $60 \mathrm{~mol} \mathrm{yr}^{-1}$ marsh-wide, while $\mathrm{PO}_{4}{ }^{3-}$ showed net uptake. Measured exports should be considered maximum estimates to the extent that evapotranspiration may have concentrated tidal water inputs. However, as plants take up, rather than exclude, both nitrate and ammonium this effect is likely to be more significant for DOC estimates.

\section{DISCUSSION}

Seepage of water through the creekbanks of Great Sippewissett Marsh was a major component of the creekbank water balance and the major pathway for transfer from below-ground carbon and nitrogen pools to tidal water. The seasonal variation in seepage losses of water and solutes indicated that plant activity, not just physical processes, plays an important role in both the hydrology and biogeochemistry of creekbank sediments.

\section{Subsurface hydrology}

Determination of both the volume of water loss and the area of marsh contributing to seepage have been general themes to most studies of porewater drainage in salt marshes. The results indicate that movement of porewater more than a few meters ( 2 to $4 \mathrm{~m}$ ) inland from creeks is predominantly through evapotranspiration with negligible drainage (Figs. 1 \& 2 ; Dacey \& Howes 1984). While a few studies have suggested that drainage of porewater from interior marsh areas may be large ( $\left.>10 \mathrm{l} \mathrm{m}^{-2} \mathrm{~d}^{-1}\right)$, the rates were based upon relatively insensitive indirect measures of water loss (changes in wet weight) or inferred fluxes required to balance measured consumption of labile solutes within the sediments. The more general finding has been that, similar to our results, porewater drainage is predominantly a near-creek phenomenon whether based upon heat (Redfield 1965) or chloride (Lord \& Church 1983) balances, or models based upon Darcy's Law (Jordan \& Correll 1985, Yelverton \& Hackney 1986, Nuttle 1988) with qualitative support from subsurface dye studies (Nestler 1977b, Jordan \& Correll 1985). 
The actual extent of lateral seepage of porewater is, of course, dependant on the physical and tidal properties of each marsh. However, it is likely that much of the difference in the inland extent of drainage is related to flooding frequency and to a lesser extent differences in hydraulic conductivity (Harvey et al. 1987). The results of subsurface models generally indicate that between 80 and $90 \%$ of the seepage loss after a flood tide is from within 2 to $3 \mathrm{~m}$ of the creek. However, if there is a steep hydraulic gradient due to rapid changes in surface elevation close to the creek as found in some narrow fringe marshes (Harvey et al. 1987), the lateral extent of drainage may be larger. The effect of flooding frequency is that with infrequent flooding the longer period of water loss results in a shift of the hydraulic gradient inland extending the area of lateral flux (Nuttle 1988). Although during spring tides Belle Isle Marsh (Nuttle 1988) and Great Sippewissett Marsh appear to have similar distributions of seepage, the greater lateral porewater movement predicted for Belle Isle is likely due to its greater elevation and irregular flooding.

At present the precise inland limit of lateral porewater movement is unclear not only because it varies with patterns of water removal and recharge, but also because of the limitations of available measures. Lateral porewater velocities determined from models are limited primarily by measurements of hydraulic conductivity $(K)$ which can vary more than an order of magnitude over short vertical distances (Hemond \& Fifield 1982) and, to a lesser extent, horizontally. However, most models apply a uniform $K$ from creekbank to inland marsh which may lead to problems in estimating the volume of porewater moving laterally since discharge is directly proportional to $K$ and the volume of water contributed from interior marsh tends to be small. Lysimeter measurements also have sensitivity limitations since the reported small lateral flows more than a few meters from creeks gather water over several $\mathrm{m}^{2}$ but translate to drainage losses of $<10 \%$ of evapotranspiration. It is clear, however, that lateral porewater movement within the rooting zone of Spartina spp. is primarily a creekbank phenomenon and in regularly flooded wetlands likely extends only about $3 \mathrm{~m}$ inland (Fig. 2; Nuttle 1988). Extending the period during which drainage occurs may increase the area over which porewater moves laterally but the rate of discharge appears not to be increased proportionately as evidenced by the rapid decline in the rate of seepage even a few hours after high tide (Figs. 1 \& 5).

Given the diversity of salt marshes for which creekbank seepage has been measured, the reported range of discharge is relatively small, 14 to $46 \mathrm{l} \mathrm{m}^{-1}$ tide $^{-1}$ (Jordan \& Correll 1985, Yelverton \& Hackney 1986, Harvey et al. 1987) and similar to the range found in
Great Sippewissett Marsh, 3 to $231 \mathrm{~m}^{-1}$ tide $^{-1}$ (Fig. 3). The extent to which variations result from methodology or differences in creekbank height (Fig. 3) or hydraulic conductivity is unclear. However, the hydraulic conductivities for the systems with comparable creekbank heights were 4 to 78 times higher than reported for our study area (Hemond \& Fifield 1982) and had 3-fold higher seepage rates (Jordan \& Correll 1985, Yelverton \& Hackney 1986). Similarly, the 13.81 $\mathrm{m}^{-1}$ tide $^{-1}$ seepage estimate of Harvey et al. (1987) was also from a system with a greater $K$ (8-fold higher) but with a much lower surface profile. It appears the mechanism relating seepage volume to creekbank height (Fig. 3) may be generalizable to other systems.

Except for the 0 to $1 \mathrm{~m}$ of marsh directly adjacent to the creeks, evapotranspiration was the major pathway for water removal from the vegetated marsh in summer (Fig. 2). In addition, plant water uptake along creekbanks appeared to alter the pathway of water removal resulting in greater seepage in winter than in summer when plants were active (Fig. 3). The role of plant water uptake along creekbanks in accelerating water table drop over drainage alone and thereby increasing the volume of lateral seepage from the interior marsh has not been quantified. However, the relative magnitude of evapotranspiration suggests that this may be an important mechanism for increasing flow of nutrientrich porewater from more inland marsh through the rooting zone of the grasses vegetating the creekbanks (Figs. $4 \& 6$ ).

\section{Seepage and marsh biogeochemistry}

Subsurface drainage of porewater has implications to both the productivity of Spartina spp. as well as being a pathway for exchange between below-ground pools and tidal waters. While a variety of factors have been found to influence the productivity of $S$. alterniflora, almost all are related to the extent of porewater turnover and most to the root oxygen status of the plants (cf. Howes et al. 1986). Drainage of porewater through seepage from creekbanks improves the conditions for plant growth by jncreasing the oxidation state of the sediments (Howes et al. 1981, Mendelssohn et al. 1981) both directly by removing dissolved sulfide (King et al. 1982, Wiegert et al. 1983) and indirectly through increasing the rate of surface oxygen exchange through air entry (Howes et al. 1986). Oxygen loss from Spartina root systems appears to account for little of the difference in sediment oxidation between creekbanks and inland vegetated sediments (Howes \& Teal 1994). Therefore, loss of porewater through seepage, to the extent that it increases water table excursion, represents an oxidation subsidy to the 
creekbank sediments potentially affecting the plant productivity. Apparently, relative to creekbank plant production, the positive effects of drainage on sediment oxidation are greater than the negative impacts of nitrogen loss. Drainage potentially increases DIN loss both through advection and by potential stimulation of nitrification-denitrification associated with increased sediment oxidation. However, it is likely that the lower ammonium levels in porewaters of tall versus short Spartina marsh (Fig. 6; Howes et al. 1985b) help to regulate losses through this mechanism, reducing the spatial variation in nitrogen loss via this pathway within Spartina marsh.

The concept of a tidal energy subsidy to the plants growing along tidal creekbanks was originally put forward to explain productivity variations within and between tidal marshes (Odum \& Fanning 1973, Odum 1980). The tidal energy subsidy hypothesis has been supported by inter-marsh comparisons of aboveground peak biomass versus tide range in Connecticut, USA (Steever et al. 1976). While the influence of tidal amplitude on plant production is potentially through increasing porewater drainage, the mechanism has yet to be demonstrated. Our finding of greater seepage (and peak above-ground biomass) from creekbanks extending further above the creekbottom suggests an explanation of the findings of Steever et al. (1976). The effect of increasing tidal amplitude is not to increase the time for porewater drainage to occur, since the tidal cycle still has the same duration, but to increase the hydraulic gradient, hence the discharge. In Great Sippewissett Marsh, both high and low creekbanks drained for similar periods but the higher banks averaged 3 times the seepage volume (and greater water table drops) throughout the year. Since marshes with higher tidal ranges generally have deeper creeks (i.e. higher creekbanks; cf. Redfield 1972), the drainage volume and therefore the oxidation subsidy should be greater in the marshes with the greater tidal amplitude. If this hypothesis is correct, the differences in productivity between marshes related to tidal amplitude is via the same mechanism mediating the productivity gradients within Spartina marshes.

In addition to associations with plant productivity, drainage of interstitial water through creekbank sediments is a major mechanism by which the high concentrations of inorganic nitrogen within the marsh sediments (Fig. 6) and organic carbon from the high root and rhizome production can be exchanged in dissolved form with tidal waters. Net losses of both DOC and DIN through the seepage pathway were observed in the present study (Fig. 8). However, the losses were small, both on an areal basis and relative to whole marsh exchanges. While variable seasonally, net DOC loss was less than $13 \mathrm{~g} \mathrm{C} \mathrm{m}^{-1}$ creekbank $\mathrm{yr}^{-1}$. If all of the DOC in the seepage water is from only the $2 \mathrm{~m}$ directly adjacent the creek the loss is equivalent to less than $1 \%$ of the organic carbon produced belowground by the plants (700 to $960 \mathrm{~g} \mathrm{C} \mathrm{m}^{-2} \mathrm{yr}^{-1}$; Howes et al. 1985a) and is much less than the particulate losses from above-ground portions over the year (Valiela et al. 1978). Similarly, DOC transport via seepage scaled to the area of the entire marsh, $85 \mathrm{~kg} \mathrm{C} \mathrm{yr}^{-1}$, is also very small compared to DOC losses in tidal exchanges [calculated from DON losses from Valiela \& Teal (1979) using a conservative $\mathrm{C} / \mathrm{N}=10 ; 7000 \mathrm{~kg} \mathrm{C}$ $\left.\mathrm{yr}^{-1}\right]$. It appears that for Great Sippewissett Marsh and for a North Carolina marsh (Yelverton \& Hackney 1986) seepage losses of DOC are small relative to other sources of organic carbon to tidal waters.

Losses of inorganic nitrogen through the seepage pathway were also small while ortho-phosphate showed a consistent net uptake by the sediments. The uptake of $\mathrm{PO}_{4}{ }^{-3}$ was similar to observations in a tidal freshwater marsh where $\mathrm{PO}_{4}{ }^{-3}$ in seepage waters was sequestered into iron-phosphate forms within the oxidized surficial sediments with the effect that seepage waters had lower concentrations than the source porewaters (Chambers \& Odum 1990). Given that almost all of the inorganic nitrogen in salt marsh sediments is in the form of ammonium it is not surprising that ammonium made up more than $90 \%$ of the DIN loss. However, similar to DOC the magnitude of the DIN loss was small, both relative to annual plant uptake, 22.4 to $24.2 \mathrm{~g} \mathrm{~N} \mathrm{~m}^{-2} \mathrm{yr}^{-1}$ of vegetated surface (White \& Howes 1994), and whole system net ammonium loss through tidal exchange, $400 \mathrm{~kg} \mathrm{~N} \mathrm{yr}^{-1}$ (Valiela \& Teal 1979). If all of the DIN in seepage water is from the $2 \mathrm{~m}$ directly adjacent the creek, the loss of $0.9 \mathrm{~g} \mathrm{~N} \mathrm{~m}^{-2}$ of vegetated marsh is only about $3 \%$ of the annual plant uptake and less than $3 \%\left(11.5 \mathrm{~kg} \mathrm{~N} \mathrm{yr}^{-1}\right)$ of the net tidal losses. These levels, representing potential tidal losses, are about 10-fold lower than those reported in an earlier study of a brackish water marsh calculated from seepage volume and porewater concentrations from 0.5 and $2.5 \mathrm{~m}$ inland of the creek (Jordan \& Correll 1985). As reported in the earlier study and as found in the present study (Table 1), estimates of solute losses through seepage based upon inland porewater concentration measurements may overestimate the magnitude of transport via this pathway. This is further supported by the net uptake of $\mathrm{PO}_{4}{ }^{3-}$ in the present study versus a large loss calculated from porewater $\mathrm{PO}_{4}{ }^{3-}$ levels.

It appears in the present study that while losses of DOC and DIN via porewater seepage through creekbanks were small, the volume of water loss was large relative to the total water turnover within the creekbank sediments. The net effect of creekbank seepage therefore is to provide a sediment oxidation subsidy to 
the creekbank grasses by increasing air entry with only small associated losses of DIN, important as nitrogen is the nutrient limiting growth of the grasses. This dual effect is consistent with the higher productivity of Spartina alterniflora growing on creekbanks compared to inland grass stands. Therefore, while porewater drainage may be important to water turnover and plant productivity along marsh creekbanks, it does not appear to be a significant pathway for transfer of organic carbon or inorganic nutrients produced belowground to tidal waters.

Acknowledgements. We thank J. Teal, D. White and N. Millham for critical review of the manuscript; $R$. Van Etten and A. Arenouski for field assistance; Z. Mlodzinska, N. Corwin and R. Vaccaro for assistance in the chemical analyses; and Mrs M. D. Gifford and Mr A. Diddle for use of their salt marsh property. This study was supported by NSF grants BSR-8717701 and BSR-85-07356 and is contribution no. 8761 of the Woods Hole Oceanographic Institution.

\section{LITERATURE CITED}

Agosta, K. (1985). The effect of tidally induced changes in the creekbank water table on porewater chemistry. Estuar. coast. Shelf Sci. 21: 389-400

Bandscheider, K., Robinson, R. (1952). A new spectrophotometric method for the determination of nitrate in seawater. J. mar. Res. 11: $87-96$

Chambers, R. M., Odum, W. E. (1990). Porewater oxidation, dissolved phosphate and the iron curtain. Biogeochemistry 10: $37-52$

Dacey, J. W. H., Howes, B. L. (1984). Water uptake by roots controls water table movement and sediment oxidation in short Spartina marsh. Science 224: 487-489

Gardner, L. R. (1975). Runoff from an intertidal marsh during tidal exposure - recession curves and chemical characteristics. Limnol. Oceanogr. 20: 81-89

Good, R. E., Good, N. F., Frasco, B. R. (1982). A review of primary production and decomposition dynamics of the below-ground marsh component. In: Kennedy, V. S (ed.) Estuarine comparisons. Academic Press, New York p. $139-157$

Harvey, J. W., Germann, P. F., Odum, W. E. (1987) Geomorphological control of subsurface hydrology in the creekbank zone of tidal marshes. Estuar. coast. Shelf Sci. 25 $677-691$

Hemond, H. F., Fifield, J. L. (1982). Subsurface flow in salt marsh peat: a model and field study. Limnol. Oceanogr 27: $126-136$

Hemond, H. F., Nuttle, W. K., Burke, R. W., Stolzenbach, K. D (1984). Surface infiltration in salt marshes: theory, measurement and biogeochemical implications. Water Resour Res. 20: 591-600

Howarth, R. W., Giblin, A., Gale, J., Peterson, B. J., Luther, G. W. (1983). Reduced sulfur compounds in the porewaters of a New England salt marsh. Ecol. Bull. 35: 135-152

Howarth, R. W., Hobbie, J. E. (1982). The regulation of decomposition and heterotrophic microbial activity in salt marsh soils: a review. In: Kennedy, V. S. (ed.) Estuarine comparisons. Academic Press, New York, p. 183-207

Howarth, R. W., Teal, J. M. (1979). Sulfate reduction in a New
England salt marsh. Limnol. Oceanogr. 24: 999-1013

Howes, B. L., Dacey, J. W., Goehringer, D. D. (1986). Factors controlling the growth form of Spartina alterniflora: feedbacks between above-ground production, sediment oxidation, nitrogen and salinity. J. Ecol. 74: 881-898

Howes, B. L., Dacey, J. W., Teal, J. M. (1985a). Annual carbon mineralization and below-ground production of Spartina alterniflora in a New England salt marsh. Ecology 66: 595-605

Howes, B. L., Dacey, J. W., Wakeham, S. G. (1985b). Effects of sampling technique on measurements of porewater constituents in salt maxsh sediments. Limnol. Oceanogr. 30: 221-227

Howes, B. L., Howarth, R. W., Teal, J. M., Valiela, I. (1981). Oxidation-reduction potentials in a salt marsh: spatial patterns with primary production. Limnol. Oceanogr. 26: $350-360$

Howes, B. L., Teal, J. M. (1994). Oxygen loss from Spartina alterniflora and its relation to rhizosphere waterlogging. Oecologia (in press)

Jordan, T E., Correll, D. L. (1985). Nutrient chemistry and hydrology of interstitial water in brackish tidal marshes of Chesapeake Bay. Estuar. coast. Shelf Sci. 21: 45-55

Jordan, T. E., Correll, D. L. (1991). Continuous automated sampling of tidal exchanges of nutrients by brackish marshes. Estuar. coast. Shelf Sci. 32: 527-545

Katz, L. C. (1980). Effects of burrowing by the fiddler crab $U_{C d}$ pugnax. Estuar. coast. Mar. Sci. 11: 233-237

King, G. M., Klug, M. J., Wiegert, R. W., Chalmers, A. G (1982). Relation of soil water movement and sulfide concentration to Spartina alterniflora production in a Georgia salt marsh. Science 218: 61-63

Lord, C. J., Church, T M. (1983). The geochemistry of salt marshes: sedimentary ion diffusion, sulfate reduction, and pyritization. Geochim. Cosmochim. Acta 47: 1381-1391

Mendelssohn, I. A., McKee, K. L. (1988). Spartina alterniflora die-back in Louisiana: time-course investigation of soil waterlogging effects. J. Ecol. 76: 509-521

Mendelssohn, I. A., McKee, K. L., Patrick, W. H. Jr (1981). Oxygen deficiency in Spartina alterniflora roots: metabolic adaptation to anoxia. Science 214: 439-441

Menzel, D. W. Vaccaro, R. F. (1964). The measurement of dissolved organic and particulate carbon in seawater. Limnol. Oceanogr. 9: 138-142

Montague, C. L. (1982). The influence of fiddler crab burrows and burrowing on metabolic processes in salt marsh sediments. In: Kennedy, V. S. (ed.) Estuarine comparisons. Academic Press, New York, p. 283-301

Murphy, J., Riley, J. (1962). A modified single solution method for the determination of phosphate in natural waters. Analyt. Chim. Acta 27: 31-36

Nestler, J (1977a). Interstitial salinity as a cause of ecophenic variation in Spartina alterniflora. Estuar. coast. Mar Sci. 5: $707-714$

Nestler, J. (1977b). A preliminary study of sediment hydrology of a Georgia saIt marsh using Rhodamine WT as a tracer. SE Geol. 18: 265-271

Nixon, S. W. (1980). Between coastal marshes and coastal waters - a review of 20 years of speculation and research on the role of salt marshes in estuarine productivity. In: Hamilton, P., MacDonald, K. (eds.) Estuarine and wetland processes with emphasis on modeling. Plenum Press, New York, p. 437-525

Nuttle, W. K. (1988). The extent of lateral water movement in the sediments of a New England salt marsh. Water Resour. Res. 24: $2077-2085$ 
Odum, E. P. (1980). The status of three ecosystem-level hypotheses regarding salt marsh estuaries: tidal subsidy, outwelling, and detritus-based food chains. In: Kennedy, V. S. (ed.) Estuarine perspectives. Academic Press, New York, p. 485-495

Odum, E., de la Cruz, A. A. (1967). Particulate organic detritus in a Georgia salt marsh-estuarine ecosystem. In: Lauff, G. H. (ed.) Estuaries. American Association for the Advancement of Science, Washington, DC, p. 383-388

Odum, E. P. Fanning, M. E. (1973). Comparison of the productivity of Spartina alterniflora and Spartina cynosuroides in Georgia coastal marshes. Bull. Ga Acad. Sci. 31. $1-12$

Redfield, A. C. (1965). The thermal regime in salt marsh peat at Barnstable, Massachusetts. Tellus 17: 246-259

Redfield, A. C. (1972). Development of a New England salt marsh. Ecol. Monogr. 42: 201-237

Scheiner, D. (1976). Determination of ammonia and Kjeldahl nitrogen by indophenol method. Water Res. 10: 31-36

Steever, E. Z.. Warren, R. S., Niering, W. A. (1976). Tidal energy subsidy and standing crop production of Spartina alterniflora. Estuar. coast. mar. Sci. 4: 473-478

Teal, J. M. (1962). Energy flow in the salt marsh ecosystem of Georgia. Ecology 43: 614-624

Teal, J. M., Howes, B. L. (in press). Long-term stability of a salt marsh ecosystem. Limnol. Oceanogr

Turner, R. E. (1976). Geographic variations in salt marsh macrophyte production: a review. Contrib. mar. Sci. 20:47-68

Valiela, 1. (1983). Nitrogen in salt marsh ecosystems. In: Car-

This article was presented by K. R. Tenore (Senior Editorial Advisor), Solomons, Maryland, USA penter, E. J., Capone, O. C. (eds.) Nitrogen in the marine environment. Academic Press, New York, p. 469-678

Valiela, I., Teal, J. M. (1979). Nitrogen budget of a salt marsh ecosystem. Nature 280: 652-656

Valiela, 1., Teal, J. M., Deusser, W. G. (1978). The nature of the growth forms in the salt marsh grass Spartina alterniflora. Am. Nat. 112: 461-470

Valiela, I., Teal, J. M., Persson, N. Y (1976). Production and dynamics of experimentally enriched salt marsh vegetation: below-ground biomass. Limnol. Oceanogr. 21: $245-252$

Vince, S. W., Valiela, I, Teal, J. M. (1981). An experimental study of the structure of herbivorous insect communities in a salt marsh. Ecology 62: 1622-1678

White, D. S., Howes, B. L. (1994). Long-term ${ }^{15} \mathrm{~N}$-nitrogen retention in the vegetated sediments of a New England salt marsh. Limnol. Oceanogr. (in press)

Whiting, G. J., McKellar, H. N., Spurrier, J. D., Wolaver, T. J (1989). Nitrogen exchange between a portion of vegetated salt marsh and the adjoining creek. Limnol. Oceanogr. 34 $463-473$

Wiegert, R. G., Chalmers, A. G., Randerson, P. F. (1983). Productivity gradients in salt marshes: the response of Spartina alterniflora to experimentally manipulated soil water movement. Oikos 41:1-6

Yelverton, G. F. Hackney, C. T (1986). Flux of dissolved organic carbon and porewater through the substrate of a Spartina alterniflora marsh in North Carolina. Estuar coast. Shelf Sci. 22: 255-267

Manuscript first received: December 15, 1993

Revised version accepted: July 27, 1994 